\title{
The interference of piperidinopropionaphthone hydrochloride in mammalian type I and type II DNA topoisomerase reactions
}

\author{
Huseyin ISTANBULLU, Sevil ZENCIR, Agnes BERENYI, Pakize CANTURK KILICKAYA, Istvan ZUPKO, Ercin ERCIYAS, Zeki TOPCU
}

\begin{abstract}
Majority of anti-cancer drugs were shown to exert their activities by interfering with DNA topoisomerase reactions. Since the identification of Camptothecin as the topoisomerase I targeting compound, these enzymes are widely utilized in biological assays to assess the pharmaceutical significance of the synthetic and natural agents. Because a considerable number of compounds were shown to have cytostatic activities via blocking topoisomerase reactions, we aimed to identify if the previously-reported physiological activities of acetonapthones involves the interference with topoisomerase reactions. We covered topoisomerase activity and cytostatic activity evaluation of piperidinopropionaphthone hydrochloride type Mannich base (MB) to compare its bioactivities to the starting propionaphtone in order to assess the contribution of aminomethyl moiety of the compound on its bioactivity. MB was synthesized and
\end{abstract}

characterized in our laboratory. Supercoiled plasmid relaxation and decatenation assays were carried out to evaluate their biological activities in mammalian DNA topoisomerases. We also assayed the cytostatic activities using HeLa, MCF7 and A431 cell lines. Our data showed a considerable inhibition of $\mathrm{MB}$ on type I and type II DNA topoisomerases without a correlation to cytostatic assays. MB exerted a modest activity against the proliferation of MCF7 cells with an $\mathrm{IC}_{50}$ value of $27.62 \mu \mathrm{M}$. The presence of MB inhibited topo II decatenation activity as well. Results offer no direct explanation for the contradictory effects on the DNA topoisomerases and the proliferation of cancer cells in vitro. Our results are discussed in relation to potential significance of aminomethyl group of Mannich base in the course of drug-development studies.

Key words: Mannich base, Anti-cancer drugs, Decatenation, Topoisomerase I, Topoisomerase II
Huseyin Istanbullu, Ercin Erciyas

Department of Pharmaceutical Chemistry, Faculty of Pharmacy,

EgeUniversity, Izmir, 35100, Turkey

Sevil Zencir

Department of Medical Biology, Faculty of Medicine, Pamukkale University, Denizli 20070, Turkey

Agnes Berenyi, Istvan Zupko

Department of Pharmacodynamics and Biopharmacy, University of Szeged, Szeged, H-6270, Hungary

Pakize Canturk Kilickaya

Department of Pharmaceutical Biotechnology, Faculty of Pharmacy, Cumhuriyet University, Sivas, 58140, Turkey

Zeki Topcu

Department of Pharmaceutical Biotechnology, Faculty of Pharmacy, Ege University, Izmir, 35100, Turkey

Corresponding author:

Huseyin ISTANBULLU

Department of Pharmaceutical Chemistry, Faculty of Pharmacy, Ege University, 35100, Izmir, Turkey

Phone: (90) 2323113277

Fax: (90) 2323885258

Mobile: (90) 5545348359

E-mail: huseyin.istanbullu@ege.edu.tr

\section{INTRODUCTION}

A widely-applied approach in designing lead compounds is molecular combination of two potentially anticancer unites within a same molecule. Using this approach, we carried out the synthesis, structure elucidation and biological activity evaluation of an acetonapthone (AN) derivative, piperidinopropionaphthone hydrochloride (Mannich base; MB), synthesized with a naphthalene ring system having intercalator property and a Mannich base connected to naphthalene ring at position 2 as alkylating agent. Acetonapthone derivatives were previously reported to exert antispasmodic (1) and ganglioplegic (2) activities as well as partial inhibition on intracellular kinases (3). Initially, Mannich bases were synthesized as prodrugs of $\alpha$, $\beta$-unsaturated ketones since deamination of Mannich bases in vivo and under simulated in vitro conditions have been documented (4). The use of Mannich bases in cancer therapy as cytostatic has been reported by several researchers (5 - 7). $\boldsymbol{\alpha}, \boldsymbol{\beta}$-unsaturated ketones are important in cancer chemotherapy because these compounds are thiol 
alkylators with little or no affinity for amino groups $(8,9)$. Mannich bases and the related $\alpha, \beta$-unsaturated ketones are structurally different from today anticancer drugs. Thus they may be of use in treating neoplasms which have become resistant to current drugs. For example, increased GSH levels have been found in different tumor cell lines which have become resistant to the alkylating agent melphalan $(10,11)$ since thiols may be more abundant just prior to and during mitosis (12) and hence be more susceptible to alkylation. In fact, the concentration of glutathione (GSH) in cells is rapidly increased just prior to cell division (13). Besides Mannich bases provide improved aqueous solubility and hydrolytic stability of drugs like Doxorubicin.

Over the past several years, great majority anti-cancer drugs of synthetic and natural origin were shown to exert their activities by inhibiting DNA topoisomerases (14 - 20) as well as interfering in DNA-protein interactions (21). DNA topoisomerases are essential enzymes functioning in many genetic processes, by making transient breakages at nucleic acid backbone and rejoining of DNA strands (22). Transient breakages allow rotation of the DNA double helix around the intact phosphodiester bonds opposite to the enzymemediated DNA cleavages. Once the DNA is relaxed, the enzyme readily relegates the break and restores intact duplex DNA (15). These enzymes are classified as type I and type II topoisomerases according to their reaction mechanisms; Type I topoisomerases make a single-stranded break in a DNA duplex, mediate passage of the intact strand through the break, and then reseal it. Type II topoisomerases, on the other hand, create transient breaks in both strands of a duplex, pass an intact DNA segment through the break and then reseal the cleavage site $(22,23)$. Because DNA topoisomerases are important cellular targets of several compounds with or without intercalative properties, we tested $\mathrm{MB}$ and its parental compound, AN, in DNA topoisomerase reactions. We employed supercoiled plasmid relaxation and decatenation reactions using type I (topo I) and type (topo II) enzymes, respectively, as well as frequently utilized human adherent cell lines (HeLa, MCF7 and A431) to investigate the antiproliferative potency of the newly synthesized substances.

\section{MATERIALS AND METHODS}

\subsection{Materials}

All starting materials and reagents were high-grade commercial products obtained from Merck and Riedel. Human cancer cell lines HeLa (cervix adenocarcinoma) MCF7 (breast adenocarcinoma) and A431 (skin epidermoid carcinoma) were purchased from ECACC (Salisbury, UK). The cells were cultivated in minimal essential medium supplemented with $10 \%$ fetal bovine serum, $1 \%$ nonessential amino acids and antibiotic-antimycotic mixture. The thermostat contained a humidified atmosphere of 5\% $\mathrm{CO}_{2}$ at $37^{\circ} \mathrm{C}$.

\subsection{Chemistry}

3-Piperidinopropio-2-naphthone hydrochloride (MB) was synthesized according to Mannich reaction conditions (24). The structure of the compound was confirmed by spectroscopic methods and elemental analyze (25). Melting points were determined with Buchi 510 capillary melting point apparatus and uncorrected. The IR spectra of compounds were monitored as potassium bromide pellets on a Jasco FT/IR-430 spectrometer. NMR spectra were recorded on a Varian AS 400 Mercury Plus NMR Spectrometer. Chemical shifts were measured in ppm $(\delta)$. Mass spectra were performed with Waters 2695 Alliance Micromass ZQ LC-MS Spectrometer Electro Spray Ionization (ESI). Elemental analyze were performed on a Thermo Finnigan EA 1112 C, H, N analyzer. UV spectra were taken on a spectrometer in methanol solution (UV160, Shimadzu, Kyoto, Japan). Analytical thin-layer chromatography (TLC) was run on Merck silica gel plates (Kieselgel $60 \mathrm{~F}_{254}$ ) with detection by UV light.

\subsection{Bioactiviy experiments}

\subsubsection{Topoisomerase I supercoiled plasmid relaxation assays}

Supercoiled plasmid relaxation assays were carried out as described (26). Briefly, $20 \mu \mathrm{L}$ of reaction mixture contained $500 \mathrm{ng}$ of supercoiled (sc) plasmid DNA in the present or absence of the test compounds, one unit of calf thymus topo I (TAKARA, Otsu-Shiga, Japan), corresponding to the activity removing the supercoils from $500 \mathrm{ng}$ of sc plasmid substrate at $37^{\circ} \mathrm{C}$ in the reaction buffer $[35 \mathrm{mM}$ Tris- $\mathrm{HCl}$ (pH 8.0), $72 \mathrm{mM} \mathrm{KCl,} 5 \mathrm{mM} \mathrm{MgCl}_{2}, 5 \mathrm{mM}$ DTT, $5 \mathrm{mM}$ spermidine, and $0.1 \%$ bovine serum albumin]. Reactions were carried out 30 minutes and terminated by the addition stop buffer (5\% sarkosyl, $0.0025 \%$ bromophenol blue, $25 \%$ glycerol). Relaxation products were separated on $1 \%$ agarose gels in TBE buffer (45 mM Tris-Borate and $1 \mathrm{mM}$ EDTA, $\mathrm{pH}$ 8.0) in a horizontal electrophoresis apparatus $(5 \mathrm{~V} / \mathrm{cm})$ (Thermo EC250) and photographed under UV light after staining in ethidium bromide (Etd-Br) solution $(0.5 \mu \mathrm{g} / \mathrm{mL})$. The quantitative evaluation of relative supercoiled and relaxed bands under UV light was carried out as described (27). DNA bands were quantified from gel 
photo images using BioRad Multianalyst (ver. 1.1). Average band intensities were calculated from three independent reactions.

\subsubsection{Topoisomerase II decatenation assays}

The decatenation assay is a specific assay for topo II activity and based on detection of kinetoplast DNA, the mitochondrial DNA of Crithidia fasciculata found as a catenated network of DNA rings, the majority of which are $2.5 \mathrm{~KB}$ monomers (28). The assays were carried out using $0.2 \mu \mathrm{g}$ kinetoplast DNA (K-DNA) substrate in a final volume of $20 \mu \mathrm{l}$ in topo II reaction buffer ( $50 \mathrm{mM}$ Tris-Cl, $\mathrm{pH}$ 8.0, $120 \mathrm{mM} \mathrm{KCl}, 10 \mathrm{mM} \mathrm{MgCl}$. $0.5 \mathrm{mM}$ ATP, 0.5 $\mathrm{mM}$ dithiothreitol). Reactions were terminated with stop buffer (5\% sarkosyl, $0.0025 \%$ bromophenol blue, $25 \%$ glycerol) and electrophoretic analyses of K-DNA were performed using standard agarose gel containing $0.5 \mu \mathrm{g}$ Etd-Br $/ \mathrm{mL}$. Resolution of decatenated DNA products were monitored as stated above. Etoposide, a well-known topoisomerase II inhibitor was used as control $(0.5 \mathrm{mM})$.

\subsubsection{Cytostatic assays}

Antiproliferative effects of the test compounds were measured in vitro on three human cell lines: HeLa (cervix adenocarcinoma), MCF7 (breast adenocarcinoma) and A431 (skin epidermoid carcinoma), by using the MTT assay (29). Briefly, near-confluent cancer cells (5000/well) were seeded onto a 96-well microplate and attached to the bottom of the well overnight. On the second day, $200 \mu \mathrm{L}$ of new medium containing the test substances was added. After incubation for $72 \mathrm{~h}$ at $37{ }^{\circ} \mathrm{C}$ in humidified air with $5 \%$ $\mathrm{CO}_{2}$, the living cells were assayed by the addition of $20 \mu \mathrm{L}$ of $5 \mathrm{mg} / \mathrm{mL}$ MTT solution. MTT was converted by intact mitochondrial reductase and precipitated as blue crystals during a $4 \mathrm{~h}$ contact period. The medium was then removed, and the precipitated crystals were dissolved in $100 \mu \mathrm{L}$ of DMSO during a $60 \mathrm{~min}$ period of shaking at $25^{\circ} \mathrm{C}$. Finally, the reduced MTT was assayed at $545 \mathrm{~nm}$, using a microplate reader; wells with untreated cells were utilized as controls. All in vitro experiments were carried out on two microplates with at least five parallel wells. Camptothecin was used as positive control. Stock solutions of the tested substances $(10 \mathrm{mM})$ were prepared with DMSO. The highest DMSO concentration $(0.3 \%)$ of the medium did not have any significant effect on the cell proliferation. Their antiproliferative effects were determined in the concentration range 0.1-30 $\mu \mathbf{M}$, the dose-response curves were fitted by means of GraphPad Prism 4 (GraphPad Software, San Diego, CA, USA) and the $\mathrm{IC}_{50}$ values were calculated.

\section{RESULTS AND DISCUSSION}

Reaction of piperidine hydrochloride with paraformaldehyde and acetonaphthone (AN) led to the formation of the corresponding Mannich base (MB). The final compound has been reported for the first time in the literature with full spectral data (25).

We used plasmid DNA relaxation and DNA catenation assays in estimating biological activity. The former assay relies on the ability of topo I to relax sc DNA while the latter assay takes advantage a topo II-specific decatenation of minicircle DNA substrates. We monitored the interference by either compound according to the migration of substrate DNA molecules on agarose gel in the presence or absence of Etd-Br. A representative supercoil relaxation assay using $10 \mathrm{mg} / \mathrm{mL}$ of parental compound (AN) and its derivative (MB) is given in Fig. 1. As seen in Fig. 1, sc plasmid substrate, pBR322 (Fig. 1, lane 1) is relaxed by topo I (Fig. 1 , lane 2) in the absence of the test compounds. The supercoil relaxing activity of topo I was not influenced by $10 \%$ DMSO, used in dissolving the test compounds (Fig. 1, lane 3). However, the reaction was profoundly affected in the presence of $1 \mathrm{mg} / \mathrm{mL}$ MB (Fig. 1, lane 5) while the parental compound, AN was not effective on topo I reaction (Fig. 1, lane 4).

The results we obtained by using a single concentration of the compounds led us to estimate the minimum concentration of MB required for interference on topo I activity upon serial dilutions (Fig. 2). As expected, there was no interference manifested by AN throughout the concentrations we employed (Fig. 2A, lanes 1 and 5). The

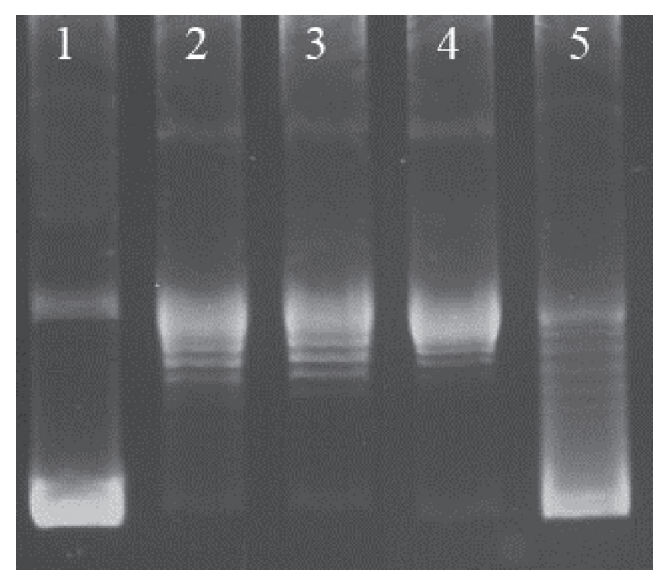

Fig. 1. The effect of 2-Acetonaphthone (AN) and its Mannich derivative, piperidinopropionaphthone hydrochloride (MB) on mammalian DNA topoisomerase I activity. Lane 1, sc plasmid substrate, pBR322; lane 2, pBR322 with $1 \mathrm{u}$ topo I; lane 3, same as lane 2 in the presence of $10 \%$ DMSO; lane 4 and 5; same as lane 2 in the presence of $1 \mathrm{mg} / \mathrm{mL} \mathrm{MB}$ and $1 \mathrm{mg} / \mathrm{mL}$ AN, respectively (see "Materials and Methods" for the details). 

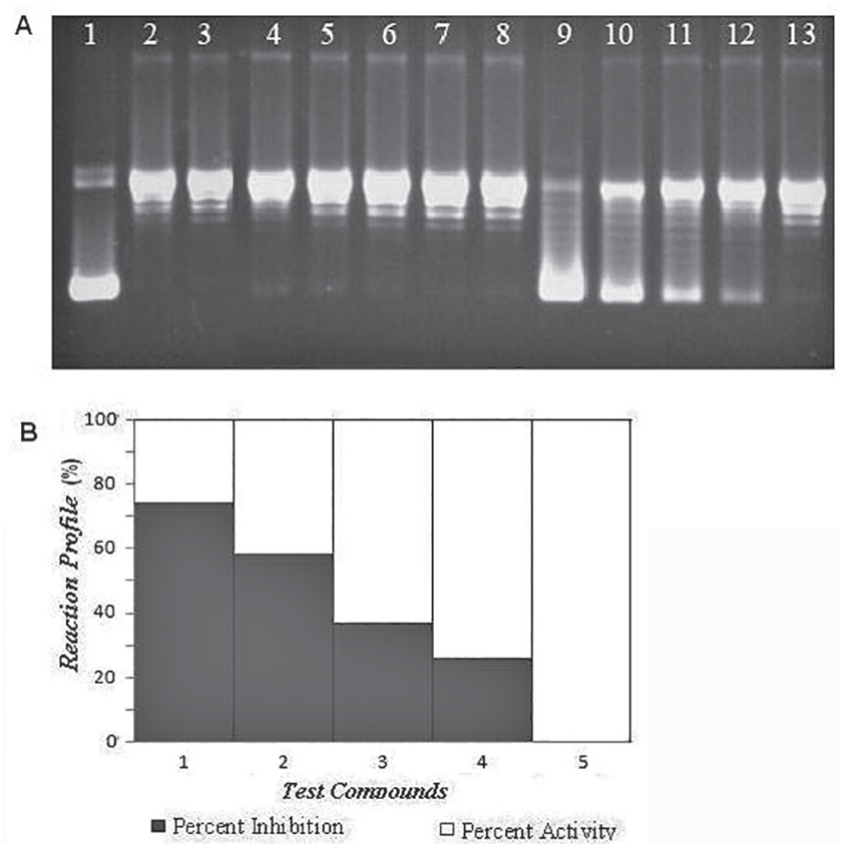

Fig. 2. A representative agarose gel photograph of supercoil relaxation in the presence of varying concentrations of test compounds and its quantitative assessment. A. Lane 1, pBR322; lane 2, pBR322 with $1 \mathrm{u}$ of DNA topoisomerase I; lane 3, same as lane 2 in $10 \%$ DMSO; lanes $4-8$, same as lane 2 plus $10 \mathrm{mg} / \mathrm{mL}, 5 \mathrm{mg} / \mathrm{mL}, 2.5 \mathrm{mg} / \mathrm{mL}, 1 \mathrm{mg} / \mathrm{mL}$ and $0.5 \mathrm{mg} / \mathrm{mL}$ of $\mathrm{AN}$, respectively; lanes $9-13$, same as as lane 2 plus $\mathrm{MB}$ in the same concentration order of lanes 4-8. B. Quantitative assessment of the reaction profile obtained with MB. The concentrations of MB from 1 to 5 correspond to $10 \mathrm{mg} / \mathrm{mL}, 5 \mathrm{mg} / \mathrm{mL}, 2.5 \mathrm{mg} / \mathrm{mL}, 1 \mathrm{mg} / \mathrm{mL}$ and $0.5 \mathrm{mg} / \mathrm{mL}$, respectively.

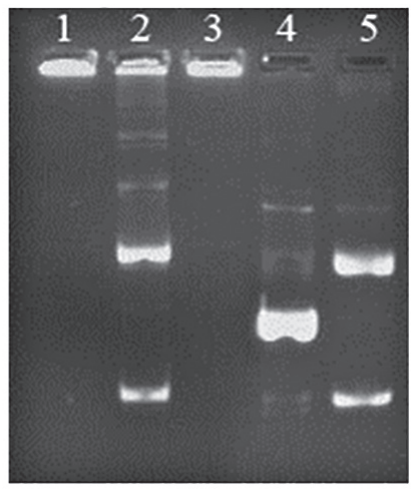

A

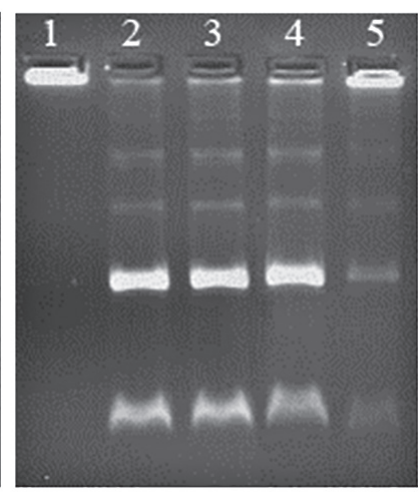

B
Fig. 3. Principle of topoisomerase II decatenation and a representative decatenation assay using the test compounds. A. A representation of topoisomerase II decatenation assay. Lane 1, catenated DNA; lane 2, catenated DNA in the presence of $1 \mathrm{u}$ Topoisomerase II; lane 3, same as lane 2 in the presence of Etoposide; lane 4, linear DNA marker; lane 5, decatenated DNA marker. B. A representative Topoisomerase II decatenation assay. Lane 1, catenated DNA without topoisomerase II; lane 2, same as lane 2 in the presence of $1 \mathrm{u}$ of Topoisomerase II; lane 3, same as lane 2 in the presence of $10 \%$ DMSO; lane 4-5, same as lane 2 in the presence of $1 \mathrm{mg} / \mathrm{mL} 2$-Acetonaphthone and Piperidinopropionaphthone hydrochloride, respectively. interference obtained by $10 \mathrm{mg} / \mathrm{mL}$ MB (Fig. 2A, lane 9) was gradually decreased upon dilution the test compound to $5 \mathrm{mg} / \mathrm{mL}$ and $2.5 \mathrm{mg} / \mathrm{mL}$ (Fig. 2A, lanes 10 and 11 , respectively). The effect was neglectable upon dilution of MB to $1 \mathrm{mg} / \mathrm{mL}$ (Fig. 2A, lane 12) as it gave rise to a very faint sc DNA band with an accumulated slower-migrating relax DNA, which eventually disappeared at $0.5 \mathrm{mg} / \mathrm{mL}$ concentration (Fig. 2A, lane 13). This indicates that the effect of MB was concentration-dependent. Densitometric calculations of relative band intensities showed that the interference was by $74 \%$ at $10 \mathrm{mg} / \mathrm{mL} \mathrm{MB}$ concentration and this value gradually decreased to $58 \%, 37 \%$ and $26 \%$ upon serial dilutions (Fig. 2B). We calculated a high $\mathrm{IC}_{50}$ value of $825 \mu \mathrm{M}$ for MB by considering residual nickedcircular DNA present in plasmid prep into account during quantitative evaluations (28).

We then monitored decatenation activity of topoisomerase II in the presence or absence of the test compounds (Fig. 3). The method takes advantage of inclusion of Etd-Br that separates open-circular (OC) monomers from covalentlyclosed circular (CCC) DNA. As seen in Fig. 3, the K-DNA was too large to enter the gel (Fig. 3A, lane 1), however, purified eukaryotic topoisomerase II yielded substantial monomeric DNA rings of two species, OC-DNA and CCCDNA (Fig. 3A, lane 2) as they were positioned with the same banding patterns of linear (Fig. 3A, lane 4) and decatenated DNA markers (Fig. 3A, lane 5). The reaction was completely abolished in the presence of Etoposide (Fig. $3 \mathrm{~A}$, lane 3). A representative decatenation assay using equal concentration of AN and MB is given in Fig. 3B. Compared to first two lanes, corresponding to catenated DNA substrate and its decatenated products by the action of topo II, AN did not exert any detectable interference (Fig. 3B, lane 4) while the presence of MB inhibited topo II decatenation (Fig. 3B, lane 5). The activity of topo II was not influenced by $10 \%$ DMSO (Fig. 3B, lane 3). The dilution of MB resulted in a diminished decatenation of the enzyme (data not shown). Because high $\mathrm{IC}_{50}$ values $(>100 \mu \mathrm{M})$ are not considered as conclusive from practical point of view as such high concentrations are rarely elicitable under in vivo conditions.

We next measured antiproliferative effects of the test compounds on three human cell lines: HeLa (cervix adenocarcinoma), MCF7 (breast adenocarcinoma) and A431 (skin epidermoid carcinoma), by using the MTT assay (29) (Fig. 4). AN exhibited no substantial cytostatic effect on the three utilized human cell lines up to $30 \mu \mathrm{M}$. Its MB congener proved to be similarly ineffective on HeLa and A431 cells but exerted a modest activity against the 


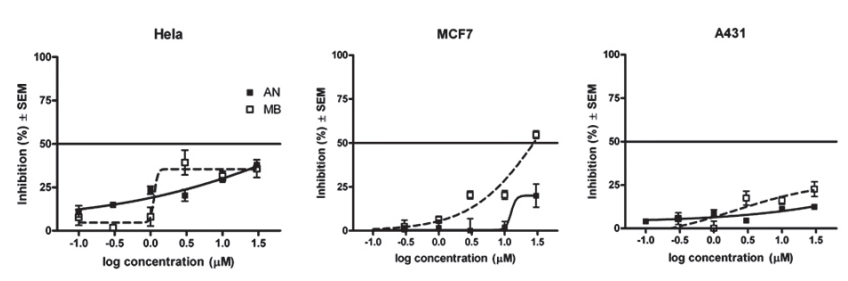

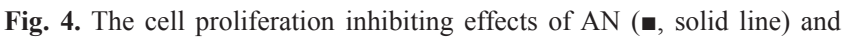
MB ( $\square$ dotted).

proliferation of MCF7 cells which could be characterized be the calculated $\mathrm{IC}_{50}$ value of $27.62 \mu \mathrm{M}$ (Fig. 4).

A relatively more profound bioactivity of final compound (MB) compared to starting ketone might be attributed to the $\boldsymbol{\alpha}, \boldsymbol{\beta}$-unsaturated ketone liberated from the Mannich bases by deamination to undergo Michael type addition with DNA nucleophiles (30).

Taken together, the presented set of results offer no direct explanation for the contradictory effects on the DNA topoisomerases and the proliferation of cancer cells in vitro. The $\mathrm{IC}_{50}$, we calculated in supercoiled plasmid relaxation reflects the nature of the assay. Indeed, $\mathrm{IC}_{50}$ value for Camptothecin, which is a well-known anti-cancer the compound, gave rise to a higher $\mathrm{IC}_{50}$ value than its expected in vitro efficacy (18 and data not shown). On the other hand, the AN and MB were added to the medium and penetration through an intact cell membrane is a condition of their action in MTT assay. A close relationship between cytostatic effect and lipid solubility of a set of alkaloids has been published earlier (31). Therefore, it could be speculated that MB has a limited capacity to enter the cell and interact with the DNA which is reflected in its poor overall antiproliferative property.

Acknowledgement: This study was supported by the grant from The Scientific and Technological Research Council of Turkey (TBAG 108T548, ZT).

\section{Piperidinopropiyonafton hidroklorür bileşiğinin tip I ve tip II memeli DNA topoizomeraz enzimleri üzerindeki etkisi}

\section{ÖZET}

Antikanser ilaçların çoğunun hücrede sıklıkla bulunan DNA topoizomeraz reaksiyonları ile girişim yaparak etkinliklerini ortaya koyduğu gösterilmiştir. Nitekim kamptotesinin (camptothecin) topoizomeraz I enzimini hedefleyen bileşik olarak tanımlanmasından itibaren sentetik ve doğal bileşiklerin farmasötik önemini değerlendirmek üzere biyolojik çalışmalarda bu enzimlerden geniş ölçüde yararlanılmıştır. Önemli sayıda bileşiğin topoizomeraz reaksiyonları üzerinden sitotoksik etkinliğe sahip olmaları nedeniyle asetonaftonun ve türevinin daha önce rapor edilen fizyolojik aktivitelerinin topoizomeraz reaksiyonlarını içerip içermediklerinin araştırılması hedeflenmiştir. Başlangıç molekülü olan asetonaftonun (AN) biyoaktivitesi ile karşılaştırılmak üzere bileşikte bulunan aminometilin biyoaktiviteye etkisi, Mannich bazı türevi olan piperidinopropiyonafton hidroklorür bileşiği (MB) ile topoizomeraz aktivite ve sitostatik aktivite ölçümleri kullanılarak değerlendirilmiştir. MB laboratuvarımızda sentezlenip karakterize edilmiştir. Memeli DNA topoizomerazları üzerindeki biyolojik aktivitelerini değerlendirmek üzere süpersarmal plazmid relaksasyon ve dekatenasyon deneyleri gerçekleştirilmiştir. Ayrıca HeLa, MCF7 ve A431 hücre hatlarında sitostatik aktivite araştırılmıştır. Verilerimize göre sitostatik değerlendirmelerden bağımsız olarak MB, tip I ve tip II DNA topoizomeraz üzerinde dikkate değer bir etki göstermiştir. MB, MCF7 hücrelerindeki proliferasyona karş1 $27.62 \mu \mathrm{M}$ olan IC50 değeri ile ortalama bir etki göstermiştir. Bununla birlikte MB varlığı topoizomeraz II dekatenasyon aktivitesini etkilemiştir. In vitro koşullarda sonuçlarımız DNA topoizomerazlar ve kanser hücrelerinin proliferasyonu üzerindeki etkilerini direkt olarak açıklamamaktadır. Sonuçlarımız Mannich bazının ilaç geliştirme çalışmalarındaki potansiyel önemi üzerinden değerlendirilmiştir.

Anahtar Kelimeler: Mannich bazı, Antikanser ilaçlar, dekatenasyon, topoizomeraz I, topoizomeraz II

\section{REFERENCES}

1. Denton JJ, Turner RJ, Neier WB, Lawson VA, Schedl HP. Antispasmodics. I. Substituted $\beta$-amino ketones. J Am Chem Soc 1949;71: 2048-50.

2. Philippot E, Denys W, Dallemagne MJ. Ganglioplegic action of several derivatives of 2,2,6,6-tetramethylpiperidine. Arch Int Pharmacodyn Ther 1962;135: 273-80.

3. Flynn GA, Lee SA, Faris M, Brandt DW, Chakravarty S. Preparation of aryl ketone derivatives as intracellular kinase inhibitors. PCT / WO 2007; 2007/136790 (A2).

4. Gordon PN, Johnston JD, English AR. $\beta$-Amino ketones as anti-infective agents. In: Antimicrobial Agents and Chemotherapy. Editor: Hobby GL. Am Soc Microbiol, Bethesda. 1965, pp 165-167.

5. Dimmock JR, Sidhu KK, Chen M, Reid RS, Allen TM, Kao 
GY, Truitt GA. Evaluation of some mannich bases of cycloalkanones and related compounds for cytotoxic activity. Eur J Med Chem 1993;28: 313-22.

6. Gul HI, Gul M, Erciyas E. Syntheses and stability studies of some mannich bases of acetophenones and evaluation of their cytotoxicity against Jurkat cells. Arzneimittel-Forsch 2002;52: 628-35.

7. Tramontini M, Angiolini L, Ghedini N. Mannich bases in polymer chemistry. Polymer 1988; 29:771-788.

8. Friedman M, Cavins JF, Wall JS. Relative nucleophilic reactivities of amino groups and mercaptide ions in addition reactions with $\alpha, \beta$-unsaturated compounds. J Am Chem Soc 1965;87: 3672-82.

9. Erciyas E, Erkaleli HI, Cosar G. Antimicrobial evaluation of some styryl ketone derivatives and related thiol adducts. J Pharm Sci 1994;83: 545-8.

10. Barranco SC, Townsend CM Jr, Weintraub B, Beasley EG, MacLean KK, Shaeffer J, Liu NH, Schellenberg K. Changes in glutathione content and resistance to anticancer agents in human stomach cancer cells induced by treatments with melphalan in vitro. Cancer Res 1990;50: 3614-8.

11. Medh RD, Gupta V, Awasthi YC. Reversal of melphalan resistance in vivo and in vitro by modulation of glutathione metabolism. Biochem Pharmacol 1991;42: 439-41.

12. Schauenstein E, Noehammer G, Rauch HJ, Kresbach H. Significant decreases in the intensity of staining for proteins and protein thiols in basal-cell epitheliomas (basaliomas) as compared to normal skin. Histochemistry 1985;83: 451-4.

13. Stern H. Sulfhydryl groups and cell division. Science (Washington DC) 1956;124: 1292-3.

14. Alpan AS, Gunes HS, Topcu Z. 1H-Benzimidazole derivatives as mammalian DNA Topoisomerase I inhibitors. Acta Biochim Pol 2007;54: 561-5.

15. Chhatriwala H, Jafri N, Salgia R. A review of Topoisomerase inhibition in lung cancer. Cancer Biol Ther 2006;12: 1600-7.

16. Ishar MPS, Singh G, Singh S, Sreenivasan KK, Singh G. Design, synthesis, and evluation of novel 6-chloro-/ fluorochromone derivatives as potential topoisomerase inhibitor anticancer agents. Bioorg Med Chem Lett 2006;16: 1366-70.

17. Kucukoglu O, Ozturk B, Kamataki T, Topcu Z. Inhibitory activities of Helichrysum taxa on mammalian Type I DNA topoisomerase. Pharm Bio 2006;44: 189-93.
18. López-Lázaro M, Martín-Cordero C, Toro MV, Ayuso MJ. Flavonoids as DNA Topoisomerase I poisons. J Enzyme Inhib Med Chem 2002;17: 25-9.

19. Martín-Cordero C, López-Lázaro M, Gálvez M, Ayuso MJ. Curcumin as a DNA Topoisomerase II poison. J Enzyme Inhib Med Chem 2003;18: 505-9.

20. Topcu Z, Ozturk B, Kucukoglu O, Kilinc E. Flavonoids in Helichrysum pamphylicum inhibit mammalian type I DNA Topoisomerase. Z Naturforsch C 2008;63: 69-74.

21. Topcu Z, Borden KLB. The yeast two-hybrid system and its pharmaceutical significance. Pharm Res 2000;17: 1049-55.

22. Wang JC. DNA topoisomerases. Ann Rev Biochem 1996;65: 635-92.

23. Bjornsti MA, Osheroff N. DNA topology and enzymes. Humana Press, Totowa, New Jersey, 1999.

24. Dimmock JR, Erciyas E, Bigam GE, Kirkpatrick DL, Duke MM. Intramolecular cyclization and cytotoxicities of some Mannich bases of styryl ketones. Eur J Med Chem 1989;24: 379-83.

25. Istanbullu H, Erzurumlu Y, Ballar Kirmizibayrak P, Erciyas E. Evaluation of alkylating and intercalating properties of mannich bases for cytotoxic activity. Lett Drug Des Disc 2014;11: 1096-1106.

26. Topcu Z and Castora FJ. Mammalian mitochondrial DNA topoisomerase I preferentially relaxes supercoils in plasmids containing specific mitochondrial DNA sequences. Biochim Biophys Acta 1996;1264: 377-87.

27. Sobhani AM., Ebrahimi SA, Mahmoudian M. An in vitro evaluation of human DNA topoisomerase I inhibition by Peganum harmala L. Seeds Extract and its $\beta$-carboline alkaloids. J Pharm Pharm Sci 2002;5: 19-23.

28. Marini JC, Miller KG, Englund PT. Decatenation of kinetoplast DNA by Topoisomerases. J Biol Chem 1980;255: 4976-79.

29. Mosmann T. Rapid colorimetric assay for cellular growth and survival: Application to proliferation and cytotoxicity assays. J Immunol Methods 1983;65:55-63.

30. Dimmock JR, Erciyas E, Kirkpatrick DL, King KM. Evaluation of some azines of aminomethylacetophenones and related quaternary ammonium compounds versus the EMT6 tumor. Pharmazie 1988;43: 614-6.

31. Réthy B, Zupkó I, Minorics R, Hohmann J, Ocsovszki I, Falkay G. Investigation of cytotoxic activity on human cancer cell lines of arborinine and furanoacridones isolated from Ruta Graveolens. Planta Med 2007;73:41-8. 